\title{
ZBIÓR PIECZĘCI Z CZASÓW PROROKA JEREMIASZA
}

Najatrakcyjniejszym terenem archeologii biblijnej pozostaje Jerozolima, a w niej najwcześniejszej zasiedlone wzgórze Ofel, do którego przylgnęla nazwa "Miasta Dawidowego". Od czasu kiedy 120 lat temu, czyli w 1867 roku, dotknęła go łopata archeologa niejedno odkrycie zapisało się trwałymi zgłoskami w dziedzinie badań nad Biblią. W 1978 roku podjęto kolejną turę prac wykopaliskowych. Podczas ośmiu sezonów, tzn. do roku 1985, na Ofelu pracowała ekspedycja zorganizowana pod auspicjami „The City of David Society”. W skład tego Towarzystwa, w którym wiodącą rolę odgrywa Instytut Archeologii Uniwersytetu Hebrajskiego, wchodzi kilka instytucji: The Israel Exploration Society, The Jerusalem Foundation, przedstawiciele The International Cultural Fund, oraz grupa żydowskich sponsorów z Republiki Południowej Afryki. Dyrektorem wykopalisk został Yigal Shiloh, długoletni (od 1959 roku) profesor Uniwersytetu Hebrajskiego. We współpracy ze świetnie przygotowanym personelem oraz setkami ochotników z różnych stron świata Y. Shiloh podjął systematyczną eksplorację wybranych miejsc Ofelu.

Wśród wielu interesujących znalezisk na szczególną uwagę zasługuje odkrycie zbioru kilkudziesięciu tzw. bulli, czyli glinianych pieczęci, którymi sygnowano oficjalne dokumenty. Słowo „bulla" kojarzy się nam z uroczystym pismem papieskim dotyczącym spraw Kościoła, narodu, diecezji, zakonu czy jakiejś większej grupy wiernych. Papieski dokument zaopatrzony jest w pieczęć (łac. bulla), zawieszoną na pergaminowym pasku lub sznurku, nieraz specjalnie kolorowanym zależnie od okoliczności wydania i przeznaczenia pisma. Zdarzają się też dokumenty poufne zabezpieczone $w$ ten sposób, iż aby je przeczytać trzeba wpierw złamać pieczęć. W trakcie piątej kampanii archeologicznej (1982 r.) na północno-wschodnim stoku Ofelu natrafiono na bezcenny zbiór pieczęci pochodzących $\mathrm{z}$ ostatnich dziesięcioleci przed zburzeniem Jerozolimy przez Babilończyków w roku 586 przed Chr. Starannie wydobyte i zabezpieczone poddane zostały wszechstronnym badaniom trwającym ponad trzy lata. Dopiero pod koniec 1986 roku ukazała się publikacja, w której zawarte są bliższe informacje o niezwykłym znalezisku. Dyrektor ekspedycji Y. Shiloh oraz jego bilski współpracownik David Tarler w ostatnim ubiegłorocznym numerze kwartalnika „Biblical Archeologist” zamieścili artykul zatytułowany Bulle z Miasta Dawidowego ${ }^{1}$.

1 Y. Shiloh-D. Tarler, Bullae from the City of David. A Hoard of Seal Impressions from the Israelite Period; „Biblical Archeologist” 49 (1986) $196-209$. 


\section{ODKRYCIE ,DOMU BULII”}

Przed podjęciem prac wykopaliskowych wyznaczono na wzgórzu Ofel 12 poletek archeologicznych, które mialy być poddane systematycznej penetracji. Izraelscy uczeni zamierzali przede wszystkim porównać rozmiary i charakter kananejskiego miasta Jebuzytów, kwitnącego w epoce brązu (lata 3200-1200 przed Chr.), z zasiedleniem izraelskim, jakie nastąpiło po podboju dokonanym przez Dawida ok. 1000 r. przed Chr. Spodziewano się też, że bardziej przejrzysty stanie się okres przejściowy (lata 1200-1000), kiedy miasto pozostawało wprawdzie we władaniu Kananejczyków, lecz dookoła umacniał się i konsolidował element izraelski. Duże nadzieje wiązano z pełniejszym poznaniem Jerozolimy w czasie, kiedy była siedzibą królów $z$ dynastii Dawidowej (X-VI w. przed Chr.). Aczkolwiek w tym punkcie chodziło o uzupełnienie dość klarownego obrazu uzyskanego na podstawie wcześniejszych kampanii archeologicznych, jednak okres królewski (zwany także okresem Pierwszej Swiątyni) jest tak istotny dla zrozumienia pism Starego Testamentu oraz dziejów i natury Izraela, że $\mathrm{w}$ badaniach archeologicznych i w studiach historycznych zawsze traktuje się go $\mathrm{z}$ najwyższa powagą.

Jedna część prac wykopaliskowych koncentrowała się na południowej stronie wzgórza (pola $A_{1}$ i $A_{2}$ ) oraz $w$ dwóch miejscach $u$ podstawy wschodniego zbocza na linii podziemnego tunelu wykutego pod koniec VIII w. przed Chr. z polecenia króla Ezechiasza (pola B i J). Sporo danych dostarczyły wykopaliska przeprowadzone na samym szczycie Ofelu (pola $\mathrm{D}_{1} \mathrm{i}_{2} \mathrm{D}_{2}$ ) oraź po jego stronie zachodniej, na stoku opadającym do Doliny Tyropeonu (pole K) i w samej Dolinie nieopodal Sadzawki Siloam (pole H). Odkryto tam ślady zasiedlenia $z$ okresu Wczesnego Brązu (lata 3200-2200) i wysoko rozwiniętego miasta kananejskiego $z$ okresu Średniego Brązu II (2000-1550) oraz pozostałości izraelskiego miasta zamieszkanego od czasów Dawida (pierwsza połowa $\mathrm{X}$ w. przed Chr.) do najazdu babilońskiego. $\mathrm{Na}$ długości 120 metrów rozpoznano linię murów kananejskiej (XVIII$\mathrm{XI}$ w.) i izraelskiej ( $\mathrm{X}$-VI w.) Jerozolimy. Inna grupa prac badawczych skupiała się w północno-zachodniej części Ofelu, na polu oznaczonym umownie symbolem G. Odkryto tu resztki masywnych murów wspierających kananejską, cytadelę obronną. Wzniesiono je w XIV-XIII w. przed Chr., a więc u schyłku epoki Brązu. Wkrótce do Kanaanu od strony morza mieli przybyć Filistyni, a z Egiptu Izraelici. Masywny charakter kananejskiej budowli świadczy, że lokalni mieszkańcy poważnie liczyli się z ewentualnością obcego ataku. Tę warowną budowlę, usytuowaną na podium, którego mury dochodzą do $8 \mathrm{~m}$. wysokości, w czasach Dawida i Salomona wykorzystali Izraelici. Stwierdzono ślady izraelskich modyfikacji, dzięki którym stała się jeszcze trudniejsza do zdobycia. Sięgając 18 metrów, czyli na wysokość 6-piętrowego budynku, oddzielała tzw. Dolne Miasto, poło- 
żone na południowej stronie Ofelu, od Górnego, usytuowanego na północy, gdzie znajdowała się świątynia Salomona i pałace królewskie. Do naszych czasów ze świątyni i wystawnych rezydencji królewskich nie zachowało się nic. Po klęsce Jerozolimy kamienie ze zburzonych budowli wykorzystano do wznoszenia innych obiektów. Obraz, jaki mamy o przedsięwzięciach Salomona, opiera się na informacjach zawartych w Biblii (2 Krl 3, 1-9, 25) i materiale porównawczym pochodzącym z wykopalisk w Samarii i w Syrii. Biblia zawiera również aluzje do budynków usytuowanych na akropolu położonym na południe od terenu świątynnego. Wspomina o cytadeli i kompleksie administracyjnym obejmując je wspólną nazwą „Ofelu”. W pierwszym rzędzie nazwa oznacza cytadelę ( $2 \mathrm{Krn} \mathrm{27,} \mathrm{3;} \mathrm{33,} \mathrm{14;} \mathrm{Ne} \mathrm{3,} \mathrm{26-27;}$ 11, 21), analogicznie do "Ofelu” zbudowanego w Samarii (2 Krl 5, 24). Warownia tak dalece dominowała nad otoczeniem, że nazwę "Ofel" przeniesiono na całe wzgórze, na którym zbudowana była najstarsza Jerozolima. W efekcie ostatnich prac wykopaliskowych odkryto kamienne struktury wspierające południowo-zachodni narożnik znanej dotąd wyłącznie z Biblii cytadeli izraelskiej, utworzonej dzięki modyfikacjom i powiększeniu warowni z czasów kananejskich ${ }^{2}$. Wymowny to dowód, jak informacje zawarte w księgach Starego Testamentu wciąż potwierdzane są przez archeologię.

$\mathrm{Na}$ tym samym poletku archeologicznym w pobliżu resztek starożytnej cytadeli, mniej więcej 11 metrów poniżej grzbietu wzgórza, Odkopano pozostałości budowli wzniesionych w przeciągu VII i VI w. przed Chr. Na przełomie obydwu stuleci miasto przeżyło wzmożoną ekspansję związaną ze zniszczeniem Samarii przez Asyryjczyków w r. 722 i przemieszczeniem się ok. 200 tys. mieszkańców państwa północnego, którzy uciekając przed deportacją wroga znaleźli schronienie w Jerozolimie. Miasto rozbudowało się zwłaszcza w kierunku zachodnim, ale i w obrębie najstarszej części poszukiwano możliwości dalszej zabudowy. Na pochyłym wzgórzu tworzono niewielkie tarasy, na których wznoszono domostwa i budynki użyteczności publicznej. Część tych tarasów, schodzących stopniowo w dół aż do murów okalających miasto, w latach 60-tych odkryła K. Kenyon. Wzdłuż dwóch najwyżej położonych, w pobliżu cytadeli, natrafiono na trzy sąsiadujące ze sobą budynki. Większą część górnego tarasu zajmował tzw. dom Ahiela, zbudowany na planie charakterystycznego dla Izraelitów domu czteroizbowego. Na północ od niego stwierdzono pozostałości całkowicie spalonej izby stanowiącej fragment sąsiedniego domu. Reszta domostwa pozostaje nadal niezbadana, gdyż znajduje się poza obrębem pola oznaczonego symbolem G. Na wschód od „domu Ahiela”, na tarasie położonym 5 metrów niżej, odkopano

2 Dokładny opis zob.: Y. Shiloh, The Material Culture of Judah. and Jerusalem in Iron Age II: Origins and Influences, w: The Land of Israel: Cross roads of Civilization, ed. by Edward Li pińs ki, „Orientalia Lovaniensia Analecta"18, Leuven 1985, s. 113-146, zwłaszcza s. 117-122. 
w 1982 roku część budynku nazywanego dzisiaj „domem bulli”. Jego ściana zachodnia służyła zarazem jako mur wspierający położony wyżej taras, na którym zbudowane zostały dwa poprzednie budynki. To tłumaczy jej masywny charakter. Wielkie kamienie, tak samo jak podłogę, pokryto grubą warstwą wapienną. Obiektem badań archeologicznych była stosunkowo nieduża powierzchnia długa na 7 metrów i szeroka na metr, co znowu podyktowane było rozmiarami wyznaczonego pod eksplorację poletka archeologicznego.

\section{OKOLICZNOŚCI ZNALEZIENIA PIECZECI}

Zanim archeologowie dotarli do pozostałości domu pochodzącego z epoki królewskiej musieli usunąć warstwy zasiedlenia $\mathrm{z}$ okresu wczesno-rzymskiego (lata 37 przed Chr. - 70 po Chr.) i hellenistycznego (lata 333-37 przed Chr.). Pod warstwą hellenistyczną ukazały się ruiny zniszczonych pożarem domostw, które podzieliły los miasta splądrowanego i zburzonego podczas najazdu Babilończyków. W Biblii czytamy: „W piątym miesiącu, siódmego dnia miesiąca - był to dziewiętnasty rok króla babilońskiego Nabuchodonozora - wkroczył do Jerozolimy Nebuzaradan, dowódca straży przybocznej, sługa króla babilońskiego. Spalił świątynię Jahwe, pałac królewski i wszystkie domy Jerozolimy - wszystkie wielkie domy spalił ogniem. Całe zaś wojsko chaldejskie, które było z dowódcą straży przybocznej, zburzyło cały mur dokoła Jerozolimy" (2 Krl 25, 8-10). Przekopując warstwę spalenizny personel kierujący pracami zalecił większą czujność. Pod nadzorem D. Tarlera pieczołowicie odkrywano mury domostw. Napięcie wzmogło się, gdy zaczęto znajdować naczynia ceramiczne. W sumie naliczono ich 25, przy czym większość zachowała się w doskonałym stanie. Są wśród nich dzbany przeznaczone do przechowywania płynów, mniejsze gliniane dzbanuszki i karafki, stojaki, lampki i miseczki. Pośród znalezisk są również dwa kratery, przypominające duże greckie naczynia używane do mieszania wina z wodą. Wyróżniają się dłuższą podstawą w kształcie trąbki, na której spoczywa pięknie wykonany i starannie wypalony korpus. W spenetrowanym domu znaleziono ponadto niewielkie kamienne odważniki z napisami określającymi wagę, cztery odrobione kamienie wykorzystywane w trakcie sprawowania kultu, groty strzał wykonane $\mathrm{z}$ brązu i żelaza, żclazny pieśrcionek, ozdobny brązowy kolczyk oraz inne drobiazgi sporządzone z kamienia, brązu i żelaza.

Podczas żmudnego przeszukiwania spalonej warstwy zadbano o to, aby ostrożnie oddzielać bezkształtne grudki gliny od pokrywającej je ziemi słusznie przypuszczając, że w pozornie bezużytecznych odpadach mogą kryć się prawdziwe skarby. Jeszcze kilkadziesiąt lat temu nie prowadzono tak skrupulatnych poszukiwań, licząc przede wszystkim na znaleziska o znaczniejszych rozmiarach. Doświadczenie 
nauczyło archeologów szacunku wobec każdej grudki rozkopywanego gruntu. Ziemię ze spalonej warstwy przemieszczano w koszykach i składowano na jednym oznaczonym miejscu. Ustawicznie dokonywano doładnej kontroli biorąc niewielką ilość ziemi na przetak i starannie ją przesiewając. Zazwyczaj jest to zadanie zatrudnionych podczas wykopalisk dziewcząt, cenionych za cierpliwość i troskę o każdy drobiazg. Dopiero po pewnym czasie bystre oczy młodych ochotników wśród piasku, gliny i najrozmaitszych odpadków wypatrzyły małe odciski pieczęci. Natychmiast wstrzymano dalsze roboty zalecając skrupulatne przebadanie ziemi przeniesionej już $\mathrm{w}$ koszykach na inne miejsce. Także w niej znaleziono kilka pieczęci. Następnie kontynuowano prace spodziewając się kolejnych znalezisk. Przewidywania spełniły się: $w$ miejscu o powierzchni niespełna $1 \mathrm{~m}^{2} \mathrm{w}$ północno-zachodnim rogu domu natrafiono na inne tego typu przedmioty. W sumie znaleziono 51 pieczęci, z których aż 41 zachowało się w doskonałym stanie. Takie przedmioty są na ogół nietrwałe i przy pierwszej lepszej okazji ulegają zniszczeniu. Tym razem, na skutek pożaru, glina bulli znacznie stwardniała, co zabezpieczyło je przed rozpadem i skruszeniem. Przezorność kierownictwa i wytrwałość młodych poszukiwaczy zostały sowicie wynagrodzone.

\section{WIEK I WYGLA_D PIECZĘCI}

Pierwszą istotną wskazówkę dla określenia chronologii odkrytych pieczęci stanowi archeologiczny kontekst znaleziska. Wprawdzie od dłuższego czasu dysponujemy sporą liczbą bulli pochodzących z późnej epoki królewskiej ale o większości z nich nie potrafimy powiedzieć skąd pochodzą ${ }^{3}$. Tym razem znamy dokładne miejsce odkrycia, możemy określić jego naturę oraz porównywać wszystkie przedmioty odnalezione blisko siebie. Odkrycie to jest drugim tego rodzaju zdarzeniem $\mathrm{w}$ dziejach systematycznie prowadzonych wykopalisk w $\mathrm{Pa}$ lestynie. Podczas eksploatacji Lachisz Y. Aharoni odnalazł 17 bulli, szacowanych na VII-VI w., zdeponowanych $w$ jednym naczyniu: Były one jednak $\mathrm{w}$ nienajlepszym stanie: tylko na ośmiu odczytano imiona właścicieli. Archeologowie przekopujący „Miasto Dawidowe” mieli więcej szczęścia.

Gruba warstwa spalenizny ze śladami gwałtownych zniszczeń, jakie nastąpiły z końcem okresu Żelaza II (pocz. VI w. przed Chr.), nie pozostawia cienia wątpliwości, że chodzi o klęskę zadaną Jerozolimie przez Babilończyków. Niemal wszystkie pieczęcie ocalały, bo temperatura ognia je utrwaliła. Zmieniły wprawdzie kolor, niektóre są opaIone, ale wystarczająco czytelne. Skoro dokumenty opatrzone tymi

3 Szerzej zob.: N. Avigad, Hebrew Bullae from the Time of Jeremiah, Israel Exploration Society, Jerusalem 1986. 
pieczęciami padły ofiarą ognia w r. 586, zatem musiały być sporządzone w okresie wcześniejszym. Potwierdzaja to inne znaleziska wydobyte na światło dzienne na polu G w tej samej (X-tej) warstwie co pieczęcie. Gliniane naczynia o rozmaitych kształtach i przeznaczeniu należą do tej samej grupy ceramiki, jaką odkryto w trakcie prac wykopaliskowych w innych częściach Jerozolimy oraz w Ramat. Rachsel, Debir, Lachisz, Engedi, Kadesz Barnea itd. Wszystkie pochodzą $z$ drugiej połowy VII w. przed Chr. Kamienne odważniki znamy $z$ innych miast judzkich. Również groty strzał, wyrabiane w sposób charakterystyczny dla Scytów, Nahman Avigad odnalazł kilka lat wcześniej podczas eksploatacji Dzielnicy Żydowskiej w obrębie Starej Jerozolimy. Znajdowały się w pobliżu fortyfikacji zabezpieczających miasto od północy wybudowanych u schyłku politycznej niezależności Judy i Jerozolimy. Dane te jednoznacznie wskazują, że pieczęcie muszą pochodzić z tego samego okresu, czyli z czasów króla Jozjasza (6400-609) i jego następców (609-586). Otrzymaliśmy zatem świadectwa współczesne wystąpieniom Jeremiasza. Prorok zapowiadał dramat Jerozolinły przestrzegając jej władze i mieszkańców przed bezkrytycznym zaufaniem $\mathrm{w}$ moc oręża i wiązaniem się sojuszami z Egiptem, za co zresztą dotknęły go surowe represje.

Decydujące dla definitywnego ustalenia wieku pieczęci są badania epigraficzne, czyli dokładna analiza występującego na nich pisma. Pod względem formy litery są takie same jak te, które znamy $z$ inskrypcji sporządzonych pismem paleohebrajskim tuż przed niewolą babilońską. Są wśród nich również bulle odnalezione podczas wykopalisk w Lachisz i Beth Zur. Nowe znalezisko powiększa liczbę zabytków epigraficznych $z$ epoki królewskiej odnalezionych w ,Mieście Dawidowym". W ramach tej samej kampanii odkryto dwie kamienne inskrypcje $z$ VII w. sporządzone również przy użyciu pisma paleohebrajskiego. Po powrocie $z$ wygnania pismo to wyszło $z$ użycia, zastąpiono je bowiem aramejskim pismem kwadratowym. Odciski pieczęci są znormalizowane. Ich długość wynosi $1,4 \mathrm{~cm}$, szerokość $1,2 \mathrm{~cm}$, natomiast grubość glinianych bulli waha się od 0,2 do $0,6 \mathrm{~cm}$. Są to więc znalıziska bardzo małe $\mathrm{i}$ to tłumaczy, dlaczego niezbędna była przezorność i ostrożność archeologów. Na odwrotnej stronie wielu bulli zochowało się odbicie sznurka, którym zostały przytwierdzone do dokumentu oraz wyraźne ślady splotu pionowych i poziomych włókien papirusu odbite wówczas, gdy wilgotny kawałek gliny połączono z materiałem piśmienniczym. Gdzieniegdzie na obrzeżach zachowały się nawet odciski palców. Nie ulega wątpliwości, że chodzi o dokumenty oficjalne, tylko takie bowiem sygnowano "bullami”. Spełniały one tę samą rolę co stemple i pieczęcie przystawiane w naszych czasach. Urzędowe dokumenty zwijano albo składano, zapisem do środka, na coraz to mniejsze części, tak że w końcu karta papirusowa mogła zmieścić się w dłoni. Złożony dokument owijano sznurkiem, a obydwa końce sznurka łączono niewielką ilością wilgotnej 
gliny, którą cylindrycznie spłaszczano uzyskując powierzchnię o średnicy $1-1,5 \mathrm{~cm}$. W glinie odbijano pieczęć właściciela. Dokument opatrzony bywał więcej aniżeli jedną pieczęcią. Dotyczyło to zwłaszcza rozmaitych kontraktów i umów sygnowanych przez obie strony oraz świadków. Aby zapis odczytać, należało najprzód złamać pieczęć. Skoro $\mathrm{w}$ trakcie wykopalisk odnaleziono całe pieczęcie zatem $\mathrm{w}$ chwili pożaru dokumenty pozostawały ,zamknięte”. Z uwagi na to, że pojedyńczy dokument mógł być opatrzony kilkoma pieczęciami, nie jesteśmy w stanie powiedzieć, ile zapisów znajdowało się w ,domu bulli" w dniu, kiedy został strawiony ogniem.

Prawie wszystkie pieczęcie (47 na ogólną liczbę 51) mają charakter epigraficzny, czyli zawiera a inskrypcje. $Z$ tego 41 napisów można dość łatwo odczytać. To bardzo dużo w porównaniu do innych tego rodzaju znalezisk. Na odciskach pieczęci znajdujemy standartową formułę, typową dla VII-VI w. przed Chr., zawierającą imię właściciela oraz imię jego ojca. Zazwyczaj jest ona ułożona według wzoru „A syn B”, ale czasami słowo „syn” (hebr. ben) bywa opuszczone. $\mathrm{Na}$ bullach $\mathrm{z}$ inskrypcjami, poza poziomymi geometrycznymi ozdobami w środku, nie ma wizerunków. Jedynie na nielicznych pojawiają się uproszczone motywy kwiatowe. Wskazuje to na odstępowanie od praktyki sporządzania obrazków typowej dla wcześniejszej fazy dziejów Izraela. Tylko na 4 pieczęciach spotykamy wyobrażenia, a mianowicie rysunek gryfa, szalę wagi oraz ołtarz lub jakiś symbol bóstwa. Nie ma na nich żadnego napisu. Uczeni są zgodni, że chodzi o wpływy z północy Palestyny. Motywy geometryczne i kwiatowe były tam bardzo popularne szczególnie w IX i w VIII w., lecz dawały o sobie znać i później. Inksrypcje pozbawione rysunków rozpowszechniły się na dobre pod koniec epoki królewskiej. Na inskrypcjach świeżo odnalezionych bulli występują wszystkie litery alfabetu paleohebrajskiego, co wydatnie wzbogaca naszą wiedzę o nim i stanowi cenny przyczynek do badań z zakresu krytyki tekstu biblijnego. W analizie paleograficznej naukowcy z Uniwersytetu Hebrajskiego zwrócili uwagę na charakterystyczny sposób pisania takich liter alfabetu jak "alef”, „daleth", „he”, „waw”, „mem” i „resz”. Poczynione spostrzeżenia okazały się rozstrzygające dla ustalenia dokładnej chronologii. Pokrywają się one $z$ danymi uzyskanymi $w$ oparciu o analizę kontekstu znaleziska. Nowo odkryte pieczęcie mieszczą się $\mathrm{w}$ przedziale czasowym między ok. 650 r. a upadkiem Jerozolimy w 586 r. przed Chr.

\section{BEZCENNE SWIADECTWA EPOKI JEREMIASZA}

Bulle z "Miasta Dawidowego" rzucają wiele nowego światła na schyłkowy okres istnienia Judy i Jerozolimy zakończony katastrofą niewoli babilońskiej.

Zacznijmy od rezultatów osiągniętych dzięki wnikliwej analizie 
imion (dziedzina onomastyki). $\mathrm{Na} 41$ czytelnych pieczęciach podających imiona właściciela $\mathrm{i}$ jego ojca (w sumie 82 imiona) doliczono się 51 różnych imion hebrajskich, $z$ których pewna liczba występuje więcej aniżeli jeden raz. Generalnie imiona są podobne do tych, jakie znamy z bulli odkrytych przez Y. Aharoniego w Lachisz. Najczęstszeimiona to Eliszama (pojawia się 4 razy) oraz Azaryahu, Bilgai, Hoszayahu i Zakkur (po 3 razy). Pozostałe imiona występują dwukrotnie albo tylko jeden raz. Ponad połowa wszystkich imion (52) to imiona teoforyczne, czyli takie, które zawierają komponent imienia Boga (jak np. polskie: Bogumił, Bogusław, Bożydar itp.). W 41 przypadkach jest to rdzeń yhw (spółgłoski imienia Jahwe) umieszczony na końcu imienia (np. Azaryahu, Benayahu, Michayahu, Zecharyahu, Zefanyahu), w 3 przypadkach na początku imienia (np. Yehobab), a 8 imion rozpoczyna się od słowa $E l$, które we wszystkich językach semickich, a więc i w hebrajskim, oznacza bóstwo i Boga (np. Eliszama). Pozostałe 30 imion (ok. $39 \%$ całości) nie są teoforyczne, aczkolwiek wiele $z$ nich stanowi skróconą formę imion teoforycznych ( $n$, Ezer zamiast Azaryahu, Szafan zamiast Szafanyahu, Zakkur zamiast Zacharyahu). Pomimo że poszczególne imiona z pieczęci brzmią tak samo jak te, które znamy $\mathrm{z}$ innych źródeł historycznych $\mathrm{z}$ tego samego okresu, to jednak układy imion ojca i syna są na tyle oryginalne, że zaledwie $\mathrm{w}$ jednym przypadku natrafiamy na imiona o takim brzmieniu, jakie znamy $z$ pieczęci znalezionej niegdyś $w$ Jerozolimie i opublikowanej kilkanaście lat temu (,Azaryahu syn Chilkiyahu"). Wśród nowoodkrytych bulli stwierdzono dwie sporządzone tą samą pieczęcią („Efrach Achiyahu”) oraz dwie odmienne pieczęcie należące prawdopodobnie do tego samego właściciela („Elnathan syn Bilgaia"). Reszta bulli stanowiła własność różnych osób. Jedne zostały lepiej, drugie nieco gorzej odciśnięte.

Różnorodność imion świadczy, że mamy do czynienia z czymś w rodzaju archiwum, w którym przechowywano oficjalne dokumenty mieszkańców Jerozolimy. Można przypuszczać, że gdyby spalone zapisy były własnością jednego człowieka czy rodziny, wtedy występujące na bullach imiona częściej by się powtarzały. W tym miejscu nasuwa się ważna obserwacja dotycząca stanu religijności w państwie południowym pod koniec VII w. przed Chr. Częstotliwość występowania imion teoforycznych wskazuje, że religijne odstępstwa z czasów króla Manassesa (699-642) i Amona (643-641), dotyczyły głównienie dworu i otoczenia królewskiego lub miały być może szerszy zakres, ale skutecznie uporano się $z$ nimi podczas rozpoczętej w r. 622 reformy Jozjasza. Można domyślać się, że tendencje synkretystyczne i jawna apostazja, jakie zaistniały w czasach bezbożnych królów, nie pozostały bez wplywu na nadawanie dzieciom imion. Skoro na pieczęciach $z$ końca VII w. stwierdzamy tak duży procent izraelskich. imion teoforycznych przemawia to za czystością wyznawanej podówczas wiary. Ponieważ na pieczęciach podaje się imiona właściciela 
i jego ojca, a więc imiona należące do dwóch generacji, należy wnosić, że pośród ojców byli ludzie, którzy pamiętali schyłek rządów Manassesa i czasy Amona. Tymczasem na pieczęciach nie znaleziono ani jednego imienia teoforycznego o charakterze nieizraelskim, co oznacza, że apostazja i uleganie obcym wpływom religijnym nie zakorzeniło się w narodzie jako całości. Obserwacja ta pozwala uściślić biblijne relacje zawarte w $2 \mathrm{Krl} 21,1-26$ oraz rozjaśnia okoliczności sukcesu reformy deuteronomistycznej: przeprowadzono ją po linii pragnień większej części narodu, który nie poszedł za przykładem. odstępców.

Nowe znaleziska uzupełniają zawarte w Starym Testamencie informacje jeszcze w inny sposób. Wśród licznych zestawów imion występujących na pieczęciach spotykamy jeden taki, który ma ścisiy związek z relacjami Biblii. Chodzi o bullę należącą do "Gemaryahu syna Szafana". Człowiek ten, współczesny królowi Jojakimowi (608598), jest czterokrotnie wzmiankowany w jednym $\mathrm{z}$ kluczowych rozdziałów Księgi Jeremiasza :,,Zdarzyło się, że w piątym roku Jojakima, syna Jozjasza, króla judzkiego, w dziewiątym miesiącu, zwołano na post przed Jahwe cały lud Jerozolimy i cały lud, który przychodził z miast judzkich do Jerozolimy. Wtedy odczytał Baruch z księgi słuchającemu ludowi słowa Jeremiasza w domu Jahwe, w sali Gemariasza, syna Szafana, kanclerza, na górnym dziedzińcu u wejścia do Bramy Nowej domu Jahwe. Usłyszał zaś Micheasz, syn Gemariasza, syna Szafana, wszystkie słowa Jahwe z księgi. I wszedł do domu królewskiego, do komnaty kanclerza. Siedzieli tam wszyscy przywódcy: Eliszama, kanclerz, Delajasz syn Szemajasza, Elnatan syn Akbora, Gemariasz syn Szafana, Sedecjasz syn Chananiasza i pozostali dostojnicy. Oznajmił im Micheasz wszystkie słowa, jakie usłyszał, gdy Baruch czytał z księgi słuchającemu ludowi" (Jr 36, 9-13). O mowie podyktowanej Baruchowi przez Jeremiasza powiadomiono króla, który nakazał przynieść zwój. „Judi więc zabrał go z komnaty kanclerza Eliszamy i czytał go w obecności króla i w obecności wszystkich dostojników, stojących przy królu. Król przebywał w rezydencji zimowej jak zwykle w dziewiątym miesiącu, a naczynie $z$ rozżarzonymi węglami płonęło przed nim. Gdy Judi przeczytał trzy lub cztery kolumny, odcinał je król nożem pisarskim i rzucał do ognia, który był w naczyniu, dopóki cały zwój nie spłonął w ogniu naezynia. Król i wszyscy jego dworzanie słysząc te słowa nie przelękli się ani nie rozdarli swoich szat. Elnatan jednak, Delajasz i Gemariasz nalegali na króla, aby nie palił zwoju. Lecz ich nie usłuchał. I rozkazał król Jerachmeelowi, synowi królewskiemu, Serajaszowi synowi Azriela, i Szelemiaszowi synowi Abdeela, pochwycić Barucha, sekretarza, oraz proroka Jeremiasza. Ukrył ich jednak Jahwe" (Jr 36, 21-26). Oprócz wzmianek o Gemariaszu dowiadujemy się o jego synu imieniem Micheasz. Ponadto w $2 \mathrm{Krl} 22,3$ czytamy o Szafanie, ojcu Gemariasza: „W osiemnastym roku króla Jozjasza posłał on (król) pisarza Szafana; 
syna Asaliasza, syna Meszullama, do świątyni Jahwe" z poleceniem zebrania pieniędzy na rzecz świątyni i dokonania wypłaty kierownikom robót. „Wówczas to arcykapłan Chilkiasz powiedział do pisarza Szafana: Znalazłem księgę Prawa w świątyni Jahwe. I dał Chilkiasz księgę Szafanowi, który ją czytał. Następnie pisarz Szafan poszedł do króla i zdał mu sprawę $z$ tego zdarzenia w słowach: Słudzy twoi wybrali pieniądze znajdujące się w świątyni i wręczyli je kierownikom robót nadzorujących w świątyni Jahwe. I pisarz Szafan oznajmił królowi: Kapłan Chilkiasz dał mi tę księgę - i Szafan odczytał ją wobec króla" (2 Krl 22, 8-10).

Do chwili ostatniego odkrycia archeologia biblijna dysponowała 3 inskrypcjami, których imiona identyfikowano $\mathrm{z}$ postaciami wspomnianymi $\dot{w}$ Biblii ${ }^{4}$. Były to bulle, na których N. Avigad rozpoznał postać „Berachyahu, syna Neriyahu, pisarza”, czyli Barucha, syna "Neriasza ( $\mathrm{Jr}$ 36, 4 i in.), „Jerachmeela, syna królewskiego” ( $\mathrm{Jr} 36$, 26) oraz „Serayahu (syna) Neriyahu”, czyli Serajasza brata Barucha (Jr 51, 59). Obecnie dochodzi do nich czwarta, która stanowiła własność Gemariasza, pisarza i zarazem kanclerza. Jego rodzina była bardzo mocno związana $\mathrm{z}$ dworem królewskim oraz losami reformy deuteronomistycznej. Ojciec Gemariasza, Szafan, w 18 roku rządów Jozjasza (622 r. przed Chr.) był bezpośrednim uczestnikiem epizodu odnalezienia księgi Prawa i zainicjowania odnowicielskiej reformy. Gemariasz pozostał wierny tym ideałom stając $w$ osiemnaście lat później (r. 604) w obronie proroka Jeremiasza. Nie inaczej postępował wnuk Szafana, Micheasz. Bulla $z$. Ofelu należała do osoby blisko związanej z prześladowanym prorokiem i jego orędziem. Chodzi o ten sam okres, w którym żyły i działały również inne osobistości znane z Biblii i z zabytków kultury materialnej: Baruch, Jerachmeel i Serajasz. Wiele do myślenia daje fakt, że dzięki szczęśliwemu zbiegowi okoliczności otrzymaliśmy solidne potwierdzenie przełomowego etapu działalności proroka Jeremiasza.

Jeszcze pod jednym względem odnalezione pieczęcie przybliżają nam czasy i osobę historycznego proroka. Pozwalają mianowicie na wierną rekonstrukcję praktyk pisarzy zatrudnianych celem spisywania dokumentów oficjalnych, poświadczania ich, pieczętowania i przechowywania. Odwołajmy się do słów Jeremiasza, który wspomina: „Przybył do mnie do wartowni (prorok był w niej przetrzymywany jako więzień króla Sedecjasza) Chanameel, syn mojego stryja, zgodnie ze słowem Jahwe i rzekł: Kup, proszę moje pole, które się znajduje w Anatot, tobie bowiem przysługuje prawo dziedzictwa i wykupu. Kup je sobie! Zrozumiałem wtedy, że było to polecenie Jahwe. Kupiłem więc pole od Chanameela, syna mojego stryja, w Anatot, i zapłaciłem mu należność - siedemnaście syklów srebra. Spisałem

4 N. Avigad, Baruch the Scribe and Jerahmeel the King's Son: .„Israel Exploration Journal” 28 (1978) 52-56. 
więc kontrakt, zapieczętowałem, wziąłem świadków i odważyłem srebro na wadze. Następnie wziąlem kontrakt kupna, dokument zapieczętowany - według przepisów prawnych - oraz otwarty i dałem kontrakt kupna Baruchowi, synowi Neriasza, syna Machsejasza, w obecności Chanameela, syna mojego stryja, i w obecności świadków, podpisanych w kontrakcie kupna, i w obecności wszystkich mieszkańców Judy przebywających w wartowni. Poleciłem zaś Baruchowi w ich obecności co następuje: To mówi Jahwe Zastępów, Bóg Izraela: Weź te dokumenty, kontrakt kupna zapieczętowany i ten, który jest otwarty, i umiesc je w glinianym naczyniu, by się zachowały przez długi czas. To bowiem mówi Jahwe Zastępów, Bóg Izraela: Będą jeszcze w tym kraju kupować domy, pola i winnice". (Jr 32, 8-15). Kontrakty, z których przetrwały jedynie bulle, zostały sporządzone w ten sam sposób. Wygląda na to, że dwa odnalezione w „domu bulli" naczynia w kształcie kraterów służyły do przechowywania gotowych dokumentów, „by się zachowały przez długi czas". W ich dolnej części zrobiono niewielkie otwory najwidoczniej w tym celu, aby nie dopuścić do nagromadzenia się wilgoci. Dobrze wypalone i suche właściwie zabezpieczały dokumenty, które do nich miały być złożone. Wszystko przemawia za tym, że archeologowie natrafili na publiczne archiwum, być może rodzaj kancelarii podobnej do tej związanej z osobą wspomnianego w Biblii Gemariasza syna Szafana. Najnowsze odkrycie na Ofelu daje nam dobre wyobrażenie o tym jak przebiegała transakcja dokonana przez Jeremiasza. Według zapewnień proroka była zapowiedzią odmiany położenia narodu i powrotu do spokojnych czasów, w których znowu będzie kwitło normalne życie. Zwyczajne wydarzenie zostało przez Jeremiasza zinterpretowane jako prorocka zapowiedź przekreślająca rachuby pesymistów i wlewająca pocieszenie i nadzieję na lepszy los miasta i narodu.

Znalezione na Ofelu hebrajskie bulle stanowią ważne wydarzenie w najnowszej archeologii biblijnej. Potwierdzają treść ksiąg biblijnych i uchylają tajemnicy postaci żyjących tuż przed niewolą babilońską. Zakończona w 1985 roku kolejna runda wykopalisk ujawniła tylko część skarbów "Miasta Dawidowego". Pozostałe w dalszym ciągu czekają na odkrywców. Naukowcy izraelscy zapowiadają następne ekspedycje, co nie jest rzeczą łatwą zważywszy na rosnące koszta wykopalisk i częściowe zasiedlenie Ofelu przez rodziny arabskie. Jednak trudności będą stopniowo pokonywane. A nowe kampanie archeologiczne dostarczą na pewno jeszcze niejednej sensacji.

Warszawa

KS. WALDEMAR CHROSTOWSKI 